\title{
HPV DNA detection and genotyping in 21 cases of primary invasive squamous cell carcinoma of the vagina
}

\author{
Marco Ferreira ${ }^{1}$, Mateus Crespo ${ }^{1}$, Luis Martins ${ }^{2}$ and Ana Félix ${ }^{1}$ \\ ${ }^{1}$ Serviço de Anatomia Patológica, Instituto Português de Oncologia de Lisboa Francisco Gentil, EPE, Lisboa, \\ Portugal and ${ }^{2}$ Laboratório de Virologia, Instituto Português de Oncologia de Lisboa Francisco Gentil, EPE, \\ Lisboa, Portugal
}

\begin{abstract}
Primary invasive squamous cell carcinoma of the vagina is rare, and the role of human papilloma virus in its pathogenesis remains unclear. The aims of our study were to determine the distribution of human papilloma virus genotypes in $\mathbf{2 1}$ cases of primary invasive squamous cell carcinoma of the vagina and to correlate human papilloma virus genotype with histological subtypes. Patients' clinical records were reviewed for demographic data and the stage of the disease. Tumors $(n=21)$ were classified according to the World Health Organization criteria. Human papilloma virus genotyping (INNO-LiPA HPV Genotyping) was performed in the whole series, and statistical analysis was performed with Fisher's Exact Test and with Student's $t$-test. The patients' age ranged from 36 to 88 (mean 65) years. Six cases were keratinizing squamous cell carcinoma, and 15 cases were non-keratinizing squamous cell carcinoma (seven non-keratinizing not otherwise specified, three basaloid, and five warty types). The median age of patients with keratinizing squamous cell carcinoma was 73.8 years and that of non-keratinizing squamous cell carcinoma patients was 61.5 years $(P=0.08)$. Human papilloma virus DNA was detected in 17 cases (81\%): 13 non-keratinizing squamous cell carcinoma (87\%) and four keratinizing squamous cell carcinoma $(67 \%)(P=0.31)$. The human papilloma virus genotypes identified were: $6,11,16,18$, $31,33,35,40$, and 58 , with human papilloma virus 16 DNA the most prevalent (33\%). Invasive squamous cell carcinoma of the vagina is frequently associated with human papilloma virus infection, and human papilloma virus 16 is the most common genotype. Although without statistical significance, keratinizing squamous cell carcinoma is more frequent in older patients, whereas non-keratinizing squamous cell carcinoma more frequently affects younger women. All studied histological subtypes are strongly associated with human papilloma virus infection.

Modern Pathology (2008) 21, 968-972; doi:10.1038/modpathol.2008.91; published online 23 May 2008
\end{abstract}

Keywords: vagina; squamous cell carcinoma; human papillomavirus

Human papillomavirus (HPV) has been clearly implicated in the pathogenesis of anogenital tract cancer. It has been detected in $90-100 \%$ of cervical squamous cell carcinomas ${ }^{1-3}$ and in $70-100 \%$ of anal squamous cell carcinoma. ${ }^{4-7}$ In vulvar carcinoma, reflecting the dual pathogenesis of these neoplasms, HPV has been detected in $75-100 \%$ of basaloid and warty squamous cell carcinoma and in less than $23 \%$ of keratinizing squamous cell carcinoma. ${ }^{8-11}$ There are very few detailed studies of the distribution of HPV in invasive and in situ squa-

Correspondence: Dr M Ferreira, MD, Serviço de Anatomia Patológica, Instituto Português de Oncologia de Francisco Gentil, EPE, Rua Professor Lima Basto, Lisboa 1099-023, Portugal.

E-mail: marco_franco@sapo.pt

Received 16 February 2008; revised 16 April 2008; accepted 17 April 2008; published online 23 May 2008 mous cell carcinoma of the vagina ${ }^{12-19}$ Therefore, it is not known if HPV is implicated in most cases, like in cervical carcinoma, or if there are multiple pathways of carcinogenesis, like in vulvar carcinoma. The aims of our study were to determine the distribution of HPV types in 21 cases of primary invasive squamous cell carcinoma of the vagina and to correlate the presence of HPV with histological subtypes.

\section{Materials and methods}

We searched the Department of Pathology database for all patients who had a diagnosis of primary squamous cell carcinoma of the vagina from 1989 to 2004. Patients' clinical records were reviewed for demographic data, disease's stage (standard clinical staging procedures were employed according to the 
criteria of the International Federation of Gynecology and Obstetrics-FIGO), and the clinical and radiological criteria of vaginal neoplasm origin, as advised by FIGO. ${ }^{20}$

Representative blocks of all cases were chosen. All specimens were formalin-fixed and paraffinembedded; $10 \%$ buffered formalin was used in the five cases diagnosed after the year 2000. Hematoxylin and eosin-stained sections of all tumors were reviewed and classified according to World Health Organization criteria ${ }^{21}$ by two independent pathologists (MF and $\mathrm{AF}$ ).

Tissue sections were obtained with anticontamination techniques, and one polymerase chain reaction (PCR) tube with four sections with $10 \mu \mathrm{m}$ was prepared for each case. Total cellular DNA was extracted from embedded tissue paraffin sections according to the manufacturer's instructions (INNO LiPA, Innogenetics, Gent, Belgium). Briefly, sections were incubated in $250 \mu \mathrm{l}$ of $1 \mathrm{mg} / \mathrm{ml}$ proteinase $\mathrm{K}$ in a $50 \mathrm{mM}$ Tris pH $8.01 \mathrm{mM}$ EDTA and $0.5 \%$ Tween 20 overnight at $56^{\circ} \mathrm{C}$. Proteinase $\mathrm{K}$ was inactivated at $100^{\circ} \mathrm{C}$ for $5 \mathrm{~min}$. The lysates were centrifuged at $18000 \mathrm{~g}$ for $5 \mathrm{~min}$ and used directly for PCR. Quality of extracted DNA was evaluated by PCR using $\beta$-globin specific primers, B4 (5'-GCTTCTGACC AAACTGTG- $\left.3^{\prime}\right)$ and B5 (5'-CACCACCAACTTCAT CCA $-3^{\prime}$ ) as previously described. ${ }^{22}$ Only DNA preparations yielding positive amplifications using $\beta$-globin primers were further analyzed for HPV detection and genotyping.

HPV PCR and hybridization steps were performed according to the instructions included in the INNO LiPA kit. PCR was performed in a final reaction volume of $50 \mu \mathrm{l}$ containing $10 \mu \mathrm{l}$ of the isolated DNA and $40 \mu \mathrm{l}$ of the PCR Mix, which included PCR buffer II, $2.0 \mathrm{mM} \mathrm{MgCl}_{2}, 200 \mu \mathrm{M}$ of each dNTP, 15 pmol each of the forward and reverse primers tagged with biotin at the $5^{\prime}$ end and $1.5 \mathrm{U}$ AmpliTaq Gold DNA Polymerase (Applied Biosystems, Foster City, CA, USA). Activation of the AmpliTaq Gold was carried out by a 9 -min incubation at $94^{\circ} \mathrm{C}$ and the amplification was carried out during 40 cycles of $30 \mathrm{~s}$ at $94^{\circ} \mathrm{C}, 45 \mathrm{~s}$ at $52^{\circ} \mathrm{C}$ and $45^{\circ} \mathrm{C}$ at $72^{\circ} \mathrm{C}$ with a final extension of $5 \mathrm{~min}$ at $72^{\circ} \mathrm{C}$.

Ten microliters of the PCR product were denatured in alkaline solution and incubated under stringent conditions with nitrocellulose membrane strips contained in oligonucleotide probes. The hybrids formed were detected by alkaline phosphatase-streptavidin conjugate and the substrates 55-bromo-4-chloro-3-indolylphosphate and nitroblue tetrazolium, resulting in a precipitate at the positive probe lines.

The LIPA strips were manually interpreted using the reference guide provided.

Positive and negative controls were used in every run. Positive control consisted in the positive amplification control included in the INNO-LiPA HPV Genotyping v2 Amp kit. Negative control consisted in PBS buffer that was processed simulta- neously with the patient samples in the DNA extraction and PCR step.

Statistical analyses were performed using Fisher's exact test and Student's $t$-test, and a $P$-value of $<0.05$ considered statistically significant.

\section{Results}

We retrieved 21 patients with the diagnosis of primary invasive squamous cell carcinoma of the vagina from the database. In all cases there was no previous history of cervical pathology. Tumors were confined to the vagina, without extension to the cervix or vulva. Patient age ranged from 36 to 88 (mean, 65; median, 67; s.d., 10.9) years. Two patients $(10 \%)$ had stage I disease, 13 patients $(62 \%)$ had stage II, two patients $(10 \%)$ had stage III and two patients $(10 \%)$ had stage IVA. In two cases the disease stage was not recorded.

Tumor topography was assessed: 10 cases (48\%) were located in the upper third of the vagina, five cases $(24 \%)$ in the middle third and two cases $(10 \%)$ in the lower third; one case $(5 \%)$ involved the middle and upper thirds of the vagina and two cases occupied the entire vaginal wall. In one case the exact tumor location was not registered in the patient's clinical record.

Histologically, six cases $(29 \%)$ were classified as keratinizing squamous cell carcinoma, and the remaining 15 cases $(71 \%)$ were non-keratinizing squamous cell carcinoma (seven non-keratinizing not otherwise specified [NOS], three basaloid, and five warty types). The mean age of patients with keratinizing squamous cell carcinoma was 73.8 years (median, 81.5; s.d., 20.2) and that of nonkeratinizing squamous cell carcinoma patients was 61.5 years (median, 66; s.d., 10.9) $(P=0.08)$.

Amplifiable DNA was obtained in all cases. In general, we found no significant differences in the quality of extracted DNA over the time period of tissue collection; namely, there was no correlation between HPV DNA positivity and the paraffin block age.

Table 1 lists the results of DNA detection. HPV DNA was detected in 17 cases (81\%): 13 nonkeratinizing squamous cell carcinoma $(87 \%)$ and four keratinizing squamous cell carcinoma (67\%). The presence of HPV was not correlated with the histological subtype $(P=0.31)$. The HPV genotypes identified were: $6,11,16,18,31,33,35,40$, and 58 . HPV 16 DNA was the most prevalent, being identified in seven specimens $(33 \%)$. In 16 cases high-risk HPV DNA was identified (76\%), and multiple HPV genotypes were isolated in four cases $(19 \%)$.

In four cases, HPV DNA was not detected. Patients' ages were $36,59,66$, and 88 years old. In three of these cases there were features suggestive of viral cellular changes (Figure 1a); however, typical binucleated koilocytes were not found. In the only 
Table 1 Primary squamous cell carcinoma of the vagina with tumor location, histological subtype and HPV type

\begin{tabular}{|c|c|c|c|}
\hline Case & $\begin{array}{l}\text { Tumor location } \\
\text { (thirds of the vagina) }\end{array}$ & Tumor type & $H P V D N A$ \\
\hline 1 & All & Warty & 16 \\
\hline 2 & All & Warty & Negative \\
\hline 3 & Upper and middle & Keratinizing & Negative \\
\hline 4 & Upper & Warty & 31 \\
\hline 5 & Middle & Keratinizing & 31 \\
\hline 6 & Unknown & Warty & 18 \\
\hline 7 & Upper & Keratinizing & $31,40,58$ \\
\hline 8 & Upper & Warty & 35,40 \\
\hline 9 & Middle & Non-keratinizing, NOS & 6 \\
\hline 10 & Upper & Non-keratinizing, NOS & 18 \\
\hline 11 & Upper & Non-keratinizing, NOS & 33 \\
\hline 12 & Upper & Keratinizing & 31 \\
\hline 13 & Lower & Keratinizing & Negative \\
\hline 14 & Middle & Non-keratinizing, NOS & $16,31,40,58$ \\
\hline 15 & Upper & Non-keratinizing, NOS & 16 \\
\hline 16 & Middle & Keratinizing & $6,11,31,33$ \\
\hline 17 & Lower & Basaloid & 16 \\
\hline 18 & Upper & Basaloid & Negative \\
\hline 19 & Middle & Basaloid & 16 \\
\hline 20 & Upper & Non-keratinizing, NOS & 16 \\
\hline 21 & Upper & Non-keratinizing, NOS & 16 \\
\hline
\end{tabular}

NOS, not otherwise specified.


Figure 1 (a) Histological features suggestive of viral cellular changes in a case with negative HPV DNA detection (hematoxylin and eosin stain, original magnification $\times 400$ ). (b) Another case with negative HPV DNA detection, associated with VaIN in the epithelium adjacent to the tumor (hematoxylin and eosin stain, original magnification $\times 100$ ) and with histological features suggestive of viral cellular changes (inset) (hematoxylin and eosin stain, original magnification $\times 400$ ).

case where the epithelium near the carcinoma was available for observation, histologic features similar to conventional vaginal intra-epithelial lesion (VaIN) (Figure 1b) were present.

\section{Discussion}

Primary carcinoma of the vagina is a rare neoplasm, accounting for less than $2 \%$ of all gynecological 
malignancies. ${ }^{23-25}$ Invasive squamous cell carcinoma is the most common tumor, comprising $79 \%$ of all cases. ${ }^{25}$ Despite all therapeutic advances, the overall 5-year survival rate is still poor. ${ }^{23-25}$ Owing to its rarity, the etiology of these tumors is poorly known. Very few studies have evaluated the presence of HPV in squamous cell carcinoma of the vagina (Table 2), and show discrepant results.

Regarding VaIN, the percentage of cases positive for HPV DNA varies between series, from $82^{16}$ to $100 \% .^{18}$

These discrepant results allow two possibilities: some authors consider that squamous cell carcinoma of the vagina shares etiopathogenic features with vulvar squamous cell carcinoma ${ }^{17}$ (in which one third of cases are related to HPV) and cervical squamous cell carcinoma (in which almost $100 \%$ of cases are related to HPV), while others consider that squamous cell carcinoma of the vagina is closely related to cervical squamous cell carcinoma. ${ }^{19}$

Our results suggest that, like in vulvar invasive squamous cell carcinoma, invasive squamous cell carcinoma of the vagina occur in two different groups of patients: keratinizing squamous cell carcinoma, more common in older patients (mean age: 73.8 years), and non-keratinizing squamous cell carcinoma, affecting mainly younger patients (mean age: 61.5 years). These results, nevertheless, fell short from statistical significance, probably because of the small number of cases, and, therefore, more studies are required to definitely clarify this issue. It would be interesting to evaluate if proximal squamous cell carcinoma of the vagina, like cervical squamous cell carcinoma, is more frequently associated with HPV DNA than distal vaginal neoplasms. However, a correlation between HPV DNA detection and tumor topography was not attempted as most of the cases studied involved the upper thirds of the vagina.

The high number of HPV DNA-positive cases in our series highlights the important role of HPV in the pathogenesis of squamous cell carcinoma of the vagina. The higher percentage of positive cases, when compared with previous reports, can be due to a higher sensitivity of the DNA amplification techniques employed or to different HPV infection incidence between populations. In fact, although HPV prevalence is lower in Europe than in other continents, it is comparatively higher in Portugal, and HPV16 is relatively more prevalent. ${ }^{26,27}$ Furthermore, DNA extraction from paraffin-embedded tissue is less optimal than DNA extraction from fresh tissue and, therefore, the number of positive HPV DNA cases in our series can be underestimated. This can possibly explain why in three of the four negative cases, virus-associated cellular changes could be observed in the neoplasm or in the nearby epithelium.

The percentage of HPV16 in our series is consistent with previous reports regarding positive cases (Table 2). Daling JR et al (2002) ${ }^{16}$ identified genotypes 6, 11, 16, 18 and 45 in the studied cases of invasive squamous cell carcinoma of the vagina, with HPV16 being the most common (58.3\%); Koyamatsu $\mathrm{Y}$ et al (2003) ${ }^{17}$ and Kiyahu MT et al $(1989)^{14}$ identified HPV16 and 18 (the only two genotypes studied), and the most common was also HPV16 (positive in 37.5 and $57 \%$ of cases, respectively).

Like Daling JR et $a l,{ }^{16}$ one of our cases was positive for low-risk HPV6 and 11. However, to the best of our knowledge, we report the first cases of squamous cell carcinoma of the vagina associated with HPV 31, 33, 35, 40 and 58. From these newly associated vaginal squamous cell carcinoma genotypes, only HPV40 is a low-risk virus, that was always present as a coinfection with other high-risk HPV genotypes. Despite never before being detected in invasive squamous cell carcinoma of the vagina, all these genotypes have been reported in VaIN, ${ }^{18,19}$ except for HPV33, which is a very well known highrisk type, associated with cervical squamous cell carcinoma. $^{2}$

The number of cases with HPV DNA detected in our series, sustains the concept supported by Koyamatsu Y et al (2003) $)^{17}$ that invasive squamous cell carcinoma of the vagina has transitional characteristics between cervical and vulvar carcinoma. ${ }^{17}$ Therefore, although keratinizing and non-keratinizing squamous cell carcinoma occur in dissimilar age groups, both are strongly associated with HPV, in opposition with vulvar squamous cell carcinoma, in which keratinizing carcinomas are not associated with HPV infection. ${ }^{28,29}$

To conclude, invasive squamous cell carcinoma of the vagina is frequently associated with HPV infection, and HPV16 is the most common genotype. Although without statistical significance, and similarly to vulvar squamous cell carcinoma, keratiniz-

Table 2 Previous studies of HPV detection in invasive SCC of the vagina

\begin{tabular}{|c|c|c|c|}
\hline Study & Number of cases studied & Positive cases (\%) & HPV genotypes identified \\
\hline Okagaki T et al $(1984)^{12}$ & 2 & 100 & $1,3,4,6$ \\
\hline Ostrow RS et al $(1988)^{13}$ & 14 & 21 & - \\
\hline Kiyahu MT et al $(1989)^{14}$ & 14 & 64 & 16,18 \\
\hline Ikenberg $\mathrm{H}$ et al $(1990)^{15}$ & 18 & 55.5 & - \\
\hline Daling JR et al $(2002)^{16}$ & 25 & 64 & $6,11,16,18,45$ \\
\hline Koyamatsu Y et al (2003) ${ }^{17}$ & 16 & 44 & 16,18 \\
\hline
\end{tabular}


ing squamous cell carcinoma is more frequent in older patients, while non-keratinizing squamous cell carcinoma more frequently affects younger women. All histological subtypes of squamous cell carcinoma of the vagina are strongly associated with HPV infection, as in cervical squamous cell carcinoma.

\section{Acknowledgement}

This work was presented in part at the 21st European Congress of Pathology, Istanbul, Turkey, September 8-13, 2007.

\section{Disclosure/Conflict of Interest}

The authors have no conflict of interest to declare.

\section{References}

1 Walboomers JM, Jacobs MV, Manos MM, et al. Human papillomavirus is a necessary cause of invasive cervical cancer worldwide. J Pathol 1999;189:12-19.

2 Munoz N, Bosch FX, de Sanjose S, et al. Epidemiologic classification of human papillomavirus types associated with cervical cancer. N Engl J Med 2003;348: 518-527.

3 Bosch FX, Lorincz A, Munoz N, et al. The causal relation between human papillomavirus and cervical cancer. J Clin Pathol 2002;55:244-265.

4 Williams GR, Lu QL, Love SB, et al. Properties of HPVpositive and HPV-negative anal carcinomas. J Pathol 1996;180:378-382.

5 Frisch M, Fenger C, van den Brule AJ, et al. Variants of squamous cell carcinoma of the anal canal and perianal skin and their relation to human papillomaviruses. Cancer Res 1999;59:753-757.

6 Daling JR, Madeleine MM, Johnson LG, et al. Human papillomavirus, smoking, and sexual practices in the etiology of anal cancer. Cancer 2004;101:270-280.

7 Varnai AD, Bollmann M, Griefingholt H, et al. HPV in anal squamous cell carcinoma and anal intraepithelial neoplasia (AIN). Impact of HPV analysis of anal lesions on diagnosis and prognosis. Int J Colorectal Dis 2006; 21:135-142.

8 Trimble CL, Hildesheim A, Brinton LA, et al. Heterogeneous etiology of squamous carcinoma of the vulva. Obstet Gynecol 1996;87:59-64.

9 Madeleine MM, Daling JR, Carter JJ, et al. Cofactors with human papillomavirus in a population-based study of vulvar cancer. J Natl Cancer Inst 1997;89: 1516-1523.

10 Schiffman M, Kjaer SK. Chapter 2: Natural history of anogenital human papillomavirus infection and neoplasia. J Natl Cancer Inst Monogr 2003;14-19.

11 Al-Ghamdi A, Freedman D, Miller D, et al. Vulvar squamous cell carcinoma in young women: a clinicopathologic study of 21 cases. Gynecol Oncol 2002;84: 94-101.

12 Okagaki T, Clark BA, Zachow KR, et al. Presence of human papillomavirus in verrucous carcinoma (Ackerman) of the vagina. Immunocytochemical, ultrastructural, and DNA hybridization studies. Arch Pathol Lab Med 1984;108:567-570.

13 Ostrow RS, Manias DA, Clark BA, et al. The analysis of carcinomas of the vagina for human papillomavirus DNA. Int J Gynecol Pathol 1988;7:308-314.

14 Kiyahu MT, Shibata D, Arnheim N. Detection of human papillomavirus in formalin-fixed, invasive squamous carcinomas using the polymerase chain reaction. Am J Surg Pathol 1989;13:221-224.

15 Ikenberg $\mathrm{H}$, Runge M, Göppinger A, et al. Human papillomavirus DNA in invasive carcinoma of the vagina. Obstet Gynecol 1990;76:432-438.

16 Daling JR, Madeleine MM, Schwartz SM, et al. A population-based study of squamous cell vaginal cancer: HPV and cofactors. Gynecol Oncol 2002;84: 263-270.

17 Koyamatsu Y, Yokoyama M, Nakao Y, et al. A comparative analysis of human papillomavirus types 16 and 18 and expression of p53 gene and Ki-67 in cervical, vaginal, and vulvar carcinomas. Gynecol Oncol 2003;90:547-551.

18 Sugase M, Matsukura T. Distinct manifestations of human papillomaviruses in the vagina. Int J Cancer 1997;72:412-415.

19 Srodon M, Stoler MH, Baber GB, et al. The distribution of low and high-risk HPV types in vulvar and vaginal intraepithelial neoplasia (VIN and VaIN). Am J Surg Pathol 2006;30:1513-1518.

20 Benedet JL, Bender H, Jones III H, et al. FIGO staging classifications and clinical practice guidelines in the management of gynecologic cancers. FIGO Committee on Gynecologic Oncology. Int J Gynaecol Obstet 2000;70:209-262.

21 Tavassoli FA, Devilee P, (eds). Tumours of the Breast and Female Genital Organs. IARC Press: Lyon, 2003.

22 Sheffield VC, Cox DR, Lerman LS, et al. Attachment of a 40-base-pair G+C-rich sequence (GC-Clamp) to genomic DNA fragments by the polymerase chain reaction results in improved detection of singlebase changes. Proc Natl Acad Sci USA 1989;86: 232-236.

23 Beller U, Maisonneuve P, Benedet JL, et al. Carcinoma of the vagina. Int J Gynaecol Obstet 2003;83:27-39.

24 Beller U, Benedet JL, Creasman WT, et al. Carcinoma of the vagina. FIGO 6th Annual Report on the Results of Treatment in Gynecological Cancer. Int J Gynaecol Obstet 2006;95:S29-S42.

25 Creasman WT, Phillips JL, Menck HR. The National Cancer Data Base report on cancer of the vagina. Cancer 1998;83:1033-1040.

26 Clifford GM, Gallus S, Herrero R, et al. Worldwide distribution of human papillomavirus types in cytologically normal women in the international agency for research on cancer HPV prevalence surveys: a pooled analysis. Lancet 2005;366:991-998.

27 Medeiros R, Prazeres H, Pinto D, et al. Characterization of HPV genotype profile in squamous cervical lesions in Portugal, a southern European population at high risk of cervical cancer. Eur J Cancer Prev 2005;14: 467-471.

28 Crum CP, McLachlin CM, Tate JE, et al. Pathobiology of vulvar squamous neoplasia. Curr Opin Obstet Gynecol 1997;9:63-69.

29 van der Avoort IA, Shirango H, Hoevenaars BM, et al. Vulvar squamous cell carcinoma is a multifactorial disease following two separate and independent pathways. Int J Gynecol Pathol 2006;25:22-29. 